\title{
Reclassification of Desulfovibrio desulfuricans Norway 4 as Desulfomicrobium norvegicum comb. nov. and Confirmation of Desulfomicrobium escambiense (corrig., Formerly "escambium") as a New Species in the Genus Desulfomicrobium
}

\author{
BARBARA R. SHARAK GENTHNER, ${ }^{1,2 *}$ STEPHANIE D. FRIEDMAN, ${ }^{1,2} \dagger$ AND RICHARD DEVEREUX ${ }^{3}$
}

Biogeochemical Systems Center, University of New Hampshire, Durham, New Hampshire 03824'; Center for Environmental Diagnostics and Bioremediation, University of West Florida, Pensacola, Florida 325142; and Environmental Research Laboratory, Microbial Ecology and Biotechnology Branch, U.S. Environmental Protection Agency, Gulf Breeze, Florida $32561^{3}$

\begin{abstract}
Desulfomicrobium escambiense, Desulfomicrobium baculatum, Desulfomicrobium apsheronum, and Desulfovibrio desulfuricans Norway 4 are closely related as determined by a 16S rRNA comparison (levels of relatedness, 0.976 to 0.997 ) and are distinct on the basis of levels of DNA-DNA similarity (11.1 to 27.4\%), genomic restriction fragment length polymorphism patterns, and certain phenotypic characteristics. We proposed that Desulfovibrio desulfuricans Norway 4 be renamed Desulfomicrobium norvegicum comb. nov.
\end{abstract}

The genus Desulfomicrobium contains dissimilatory sulfatereducing species that are physiologically similar to Desulfovibrio species and are straight rods which lack desulfoviridin (25), a pigment considered diagnostic for the genus Desulfovibrio (21). Recently, we described the isolation and classification of the new species Desulfomicrobium escambiense (type strain, ATCC 51164) (27). In the current study we compared the genotypic and phenotypic characteristics of Desulfomicrobium escambiense, Desulfomicrobium baculatum DSM 4028, Desulfomicrobium apsheronum DSM 5918, and Desulfovibrio desulfuricans Norway 4 ( = NCIMB 8310$)$. Our results showed that these four organisms are members of separate Desulfomicrobium species.

Growth was measured by determining increases in optical density at $600 \mathrm{~nm}\left(\mathrm{OD}_{600}\right)$ in anaerobic medium supplemented with $0.02 \%$ yeast extract $(26,28,29)$. Volatile and nonvolatile fatty acids were quantified after derivitization $(9,10)$ by comparison to derivatized autheutic standards and by using heptanoate as an internal derivitization control. Sulfate concentrations were determined by ion chromatography (27).

The 16S ribosomal DNA sequence of Desulfomicrobium apsheronum (GenBank accession no. U64865) was determined as described by Weisberg et al. $(27,32)$. Levels of similarity among Desulfomicrobium 16S rRNAs (26) were calculated as described previously (11). DNA-DNA hybridization was performed on Immobilon- $\mathrm{N}$ transfer membranes (23) as previously described (1), with the size variations of purified genomic DNA minimized by passage through a 29 -gauge needle and sonication. Genomic DNA was labeled with $\left[{ }^{32} \mathrm{P}\right] \mathrm{dCTP}$ by using a random primed DNA labeling kit (Boehringer Mannheim). Levels of heterologous DNA-DNA binding were calculated by determining percentages of similarity (8). XbaI-digested genomic DNA was analyzed by pulse-field gel electrophoresis (2, 14).

Utilization of lactate, pyruvate, formate, and hydrogen as

\footnotetext{
${ }^{*}$ Corresponding author. Mailing address: Center for Environmental Diagnostics and Bioremediation, University of West Florida, 11000 University Parkway, Pensacola, FL 32514. Phone: (904) 857-6097. Fax: (904) 474-3130. E-mail: bgenthne@uwf.edu.

† Present address: U.S. Environmental Protection Agency, Gulf Breeze, FL 32561
}

electron donors for sulfate reduction and the failure to utilize acetate, propionate, or butyrate as electron donors for sulfate reduction have been described previously for Desulfomicrobium species $(4,16,19,20,24,25,27)$. However, previous authors have disagreed on the utilization of ethanol, malate, fumarate, or choline as electron donors. Our growth and chromatographic data indicated that the four strains used in our study utilized ethanol, but not choline (data not shown), for sulfate reduction, in contrast to previous reports that Desulfomicrobium baculatum and strain Norway 4 did not use ethanol as an electron donor $(4,24)$ and that strain Norway 4 used choline (16), like other Desulfovibrio desulfuricans (22) strains.

Growth and the end products formed with pyruvate, fumarate, and malate during sulfate reduction or fermentation were compared (Table 1). Acetate was a major product of all strains in both media used. All strains formed succinate in fumaratesulfate medium, although Desulfomicrobium baculatum and strain Norway 4 formed much more succinate $(25 \mathrm{mM})$ than Desulfomicrobium apsheronum or Desulfomicrobium escambiense formed (1.0 to $8 \mathrm{mM})$. Only Desulfomicrobium baculatum and strain Norway 4 formed succinate $(7.4$ to $9.3 \mathrm{mM}$ ) in malate-sulfate medium. Lactate was formed by Desulfomicrobium escambiense and strain Norway 4 in fumarate-sulfate and malate-sulfate media, but only by Desulfomicrobium escambiense in pyruvate-sulfate medium. Interestingly, Desulfomicrobium apsheronum and Desulfomicrobium escambiense grew better $\left(\mathrm{OD}_{600}, 0.3\right.$ to 0.4$)$ with fumarate or malate in sulfate medium than Desulfomicrobium baculatum or strain Norway 4 grew $\left(\mathrm{OD}_{600}, 0.2\right)$. In these tests, Desulfomicrobium apsheronum and Desulfomicrobium escambiense reduced the sulfate, while Desulfomicrobium baculatum and strain Norway 4 preferentially reduced fumarate to succinate despite the less favorable thermodynamics (30) of the latter reaction. We found that Desulfomicrobium escambiense used fumarate and malate as electron donors in media containing yeast extract, in contrast to the negative results obtained with defined anaerobic medium (27).

Previous reports indicated that strain Norway 4 grew poorly (20) and Desulfomicrobium baculatum failed to grow $(19,24)$ by pyruvate fermentation, while Desulfomicrobium baculatum failed to ferment fumarate (24) or malate (25) and strain Norway 4 fermented both of these compounds $(15,17)$. In the 
TABLE 1. Comparison of Desulfomicrobium species and strain Norway 4 for growth by sulfate reduction or fermentation with fumarate, malate, or pyruvate

\begin{tabular}{|c|c|c|c|c|}
\hline Growth conditions & Species or strain & Growth $^{a}$ & Major organic product(s) & $\mathrm{SO}_{4}$ reduction $^{a}$ \\
\hline Fumarate and $\mathrm{SO}_{4}$ & $\begin{array}{l}\text { Desulfomicrobium apsheronum } \\
\text { Desulfomicrobium baculatum } \\
\text { Desulfomicrobium escambiense } \\
\text { Norway } 4\end{array}$ & $\begin{array}{l}+++ \\
+++ \\
+++ \\
++\end{array}$ & $\begin{array}{l}\text { Acetate, succinate } \\
\text { Acetate, succinate } \\
\text { Acetate, lactate, succinate } \\
\text { Acetate, lactate, succinate }\end{array}$ & $\begin{array}{l}++ \\
- \\
++ \\
-\end{array}$ \\
\hline Malate and $\mathrm{SO}_{4}$ & $\begin{array}{l}\text { Desulfomicrobium apsheronum } \\
\text { Desulfomicrobium baculatum } \\
\text { Desulfomicrobium escambiense } \\
\text { Norway } 4\end{array}$ & $\begin{array}{l}+++ \\
++ \\
+++ \\
++\end{array}$ & $\begin{array}{l}\text { Acetate } \\
\text { Acetate, succinate } \\
\text { Acetate, lactate } \\
\text { Acetate, lactate, succinate }\end{array}$ & $\begin{array}{l}++ \\
- \\
++ \\
-\end{array}$ \\
\hline Pyruvate and $\mathrm{SO}_{4}$ & $\begin{array}{l}\text { Desulfomicrobium apsheronum } \\
\text { Desulfomicrobium baculatum } \\
\text { Desulfomicrobium escambiense } \\
\text { Norway } 4\end{array}$ & $\begin{array}{l}++ \\
++ \\
++ \\
++\end{array}$ & $\begin{array}{l}\text { Acetate } \\
\text { Acetate } \\
\text { Acetate, lactate } \\
\text { Acetate }\end{array}$ & $\begin{array}{l}+ \\
+ \\
+ \\
+\end{array}$ \\
\hline Fumarate alone & $\begin{array}{l}\text { Desulfomicrobium apsheronum } \\
\text { Desulfomicrobium baculatum } \\
\text { Desulfomicrobium escambiense } \\
\text { Norway } 4\end{array}$ & $\begin{array}{l}+++ \\
+++ \\
+ \\
+\end{array}$ & $\begin{array}{l}\text { Acetate, succinate } \\
\text { Acetate, succinate } \\
\text { Acetate, lactate, succinate } \\
\text { Acetate, lactate, succinate }\end{array}$ & $\begin{array}{l}\text { NA } \\
\text { NA } \\
\text { NA } \\
\text { NA }\end{array}$ \\
\hline Malate alone & $\begin{array}{l}\text { Desulfomicrobium apsheronum } \\
\text { Desulfomicrobium baculatum } \\
\text { Desulfomicrobium escambiense } \\
\text { Norway } 4\end{array}$ & $\begin{array}{l}+ \\
+ \\
+ \\
+\end{array}$ & $\begin{array}{l}\text { Acetate, lactate, succinate } \\
\text { Acetate, succinate } \\
\text { Acetate, lactate, succinate } \\
\text { Acetate, lactate, succinate }\end{array}$ & $\begin{array}{l}\text { NA } \\
\text { NA } \\
\text { NA } \\
\text { NA }\end{array}$ \\
\hline Pyruvate alone & $\begin{array}{l}\text { Desulfomicrobium apsheronum } \\
\text { Desulfomicrobium baculatum } \\
\text { Desulfomicrobium escambiense } \\
\text { Norway } 4\end{array}$ & $\begin{array}{l}+ \\
\pm \\
+ \\
\pm\end{array}$ & $\begin{array}{l}\text { Acetate, lactate, succinate } \\
\text { Acetate, succinate } \\
\text { Acetate, lactate, succinate } \\
\text { Acetate, lactate, succinate }\end{array}$ & $\begin{array}{l}\text { NA } \\
\text { NA } \\
\text { NA } \\
\text { NA }\end{array}$ \\
\hline
\end{tabular}

${ }^{a}+++$, very good; ++ , good; + , fair; \pm , poor; - , none; NA, not applicable.

current study, pyruvate fermentation and malate fermentation were indicated by the formation of acetate and succinate by Desulfomicrobium baculatum and by the formation of acetate, lactate, and succinate by Desulfomicrobium escambiense, Desulfomicrobium apsheronum, and strain Norway 4. Desulfomicrobium apsheronum and Desulfomicrobium baculatum grew better $\left(\mathrm{OD}_{600}, 0.24\right.$ to 0.36$)$ by fumarate fermentation than $D e$ sulfomicrobium escambiense or strain Norway 4 grew $\left(\mathrm{OD}_{600}\right.$, 0.10 ) and formed acetate and succinate, in contrast to Desulfomicrobium escambiense and strain Norway 4, which formed acetate, lactate, and succinate. Thus, lactate was formed by Desulfomicrobium escambiense and strain Norway 4 during fermentation of all three substrates and by Desulfomicrobium apsheronum during fermentation of pyruvate or malate, but not by Desulfomicrobium baculatum during fermentation of any of the three substrates. Choline was not fermented by any of the strains tested.
16S rRNA sequence comparisons (Table 2) revealed a close relationship among the four strains examined. Desulfomicrobium baculatum, Desulfomicrobium apsheronum, and strain Norway 4 were more closely related to each other (levels of sequence similarity, 99.3 to $99.7 \%$ ) than to Desulfomicrobium escambiense (97.6 to $98.1 \%$ ). Since $16 \mathrm{~S}$ rRNA analysis alone is not sufficient to distinguish closely related species (6), DNADNA hybridization experiments were performed with the four organisms. The levels of DNA-DNA similarity (Table 2) among the four strains used ranged from 11.1 to $27.4 \%$, which is consistent with each taxon representing a unique species. The similarity value of $24.7 \%$ reported previously $(18,25)$ for Desulfomicrobium baculatum and Desulfomicrobium apsheronum is close to our value $(19.8 \%)$. Wayne et al. (31) stated that a species should include strains that exhibit $\geq 70 \%$ DNA-DNA relatedness. Strain Norway 4 exhibited only $2.1 \%$ similarity with Desulfovibrio desulfuricans ATCC 27774.

TABLE 2. Levels of DNA-DNA similarity and 16S rRNA similarity for Desulfomicrobium species

\begin{tabular}{|c|c|c|c|c|c|}
\hline \multirow[b]{2}{*}{ Species or strain } & \multicolumn{5}{|c|}{$\%$ Homology or \% similarity ${ }^{a}$} \\
\hline & $\begin{array}{l}\text { Desulfomicrobium } \\
\text { escambiense ESC1 }\end{array}$ & $\begin{array}{c}\text { Desulfomicrobium } \\
\text { apsheronum }\end{array}$ & $\begin{array}{c}\text { Desulfomicrobium } \\
\text { baculatum }\end{array}$ & Norway 4 & $\begin{array}{l}\text { Desulfovibrio } \\
\text { desulfuricans }\end{array}$ \\
\hline Desulfomicrobium escambiense ESC1 & & 0.981 & 0.981 & 0.976 & 0.871 \\
\hline Desulfomicrobium apsheronum & $11.1 \pm 13.2$ & & 0.997 & 0.992 & 0.870 \\
\hline Desulfomicrobium baculatum & $12.3 \pm 5.4$ & $19.8 \pm 22.7$ & & 0.993 & 0.877 \\
\hline Norway 4 & $13.0 \pm 5.4$ & $13.1 \pm 9.7$ & $27.4 \pm 7.1$ & & 0.877 \\
\hline Desulfovibrio desulfuricans $s^{b}$ & $1.5 \pm 1.7$ & $0.14^{c}$ & $1.8 \pm 1.3$ & $2.1 \pm 2.0$ & \\
\hline
\end{tabular}

\footnotetext{
${ }^{a}$ The values on the upper right are levels of $16 \mathrm{~S}$ rRNA similarity, and the values on the lower left are levels of DNA-DNA similarity.

${ }^{b}$ Negative control.

c There was no sample deviation, and the analysis was not repeated.
} 


\section{A B C D E F}

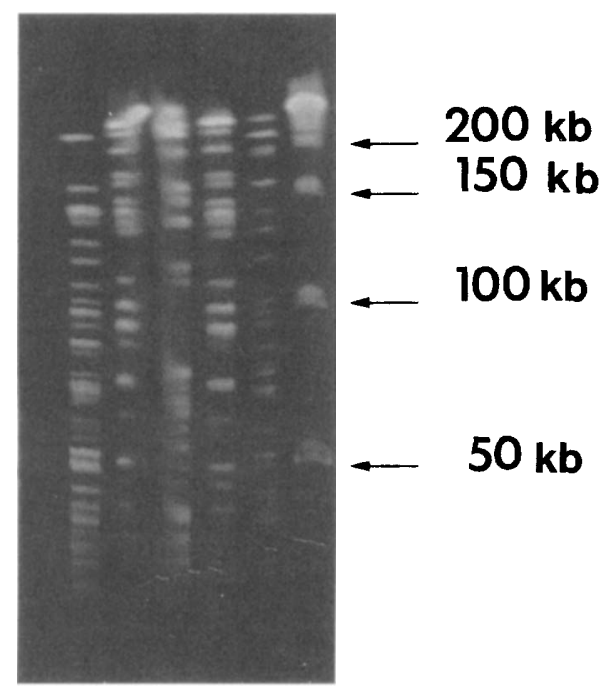

FIG. 1. Macrorestriction fragment analysis of Desulfomicrobium apsheronum (lane A), Desulfomicrobium escambiense ATCC 51164 (lane B), Desulfomicrobium baculatum (lane C), Desulfomicrobium escambiense ESC1 (lane D), strain Norway 4 (lane E), and a $\lambda$ ladder size standard (lane F) by pulse-field gel electrophoresis.

Genotypic divergence was also indicated by the results of a macrorestriction analysis $(2,3,7)$ which revealed unique fragmentation patterns for the strains examined (Fig. 1). We calculated that the $\mathrm{G}+\mathrm{C}$ content of strain Norway 4 , which has not been published previously, is $54.2 \mathrm{~mol} \%$ on the basis of a DNA thermal melting point of $92.0^{\circ} \mathrm{C}(13)$. The $\mathrm{G}+\mathrm{C}$ contents of Desulfomicrobium baculatum (24), Desulfomicrobium escambiense (27), and Desulfomicrobium apsheronum (25) are 56.8, 59.9 , and $52 \mathrm{~mol} \%$, respectively.

Desulfovibrio desulfuricans Norway 4 was first isolated from Oslo Harbor in 1949 (16). It was classified as a strain of Desulfovibrio desulfuricans on the basis of physiological similarity, despite the fact that it was a straight rod that lacked desulfoviridin. More recently, bacterial strains having these characteristics were placed in a separate genus, the genus Desulfomicrobium (25). On this basis, Fauque et al. (5) considered strain Norway 4 a strain of Desulfomicrobium baculatum $(12,16)$. Placement of a strain in a species should be based on both phylogenetic and phenotypic characteristics (31). We therefore reexamined the members of the genus Desulfomicrobium and Desulfovibrio desulfuricans Norway 4. Based on DNA-DNA hybridization values and the organic products formed from growth on malate, fumarate, and pyruvate, strain Norway 4 appears to be sufficiently different from Desulfomicrobium baculatum to be considered a member of a separate species. We propose that Desulfovibrio desulfuricans Norway 4 be renamed Desulfomicrobium norvegicum comb. nov. In addition, our phenotypic and phylogenetic information confirmed that Desulfomicrobium escambiense (es.cam.bi.en'se. M. L. adj. escambiense, pertaining to the Escambia River) is a distinct species.

Description of Desulfomicrobium norvegicum comb. nov. Desulfomicrobium norvegicum (nor.ve'gi.cum. M. L. adj. norvegicum, Norwegian). Isolated from Oslo Harbor in 1949. The type strain was originally designated Desulfovibrio desulfuricans Norway 4 and was deposited in the National Collection of Industrial Bacteria as strain NCIB 8310.

Non-spore-forming, gram-negative, sulfate-reducing, obli- gately anaerobic rods ( 0.5 to 1.0 by 3.0 to $5.0 \mu \mathrm{m})$. Uses lactate, pyruvate, ethanol, hydrogen, and formate but not acetate, propionate, butyrate, methanol, propanol, butanol, isobutanol, lactose, glucose, oxalate, or choline as electron donors for sulfate reduction. Ferments pyruvate poorly, malate well, and fumarate very well, forming acetate, lactate, and succinate. Does not ferment choline. Preferentially reduces fumarate and malate to succinate over reduction of sulfate to sulfide. Contains desulforubidin, but not desulfoviridin. The DNA $\mathrm{G}+\mathrm{C}$ content is $56.8 \mathrm{~mol} \%$. The levels of DNA-DNA homology with Desulfomicrobium apsheronum, Desulfomicrobium baculatum, and Desulfomicrobium escambiense are 13.1, 27.4, and $13.0 \%$, respectively, and the level of DNA-DNA homology with $D e$ sulfovibrio desulfuricans ATTC 27774 is $2.1 \%$. Exhibits 99.2, 99.3, and 97.6\% 16S rRNA similarity with Desulfomicrobium apsheronum, Desulfomicrobium baculatum, and Desulfomicrobium escambiense, respectively, and $87.7 \%$ 16S rRNA similarity with Desulfovibrio desulfuricans ATTC 27774. The type strain is NCIMB 8310.

We thank Brendan Manning for assistance in pulse-field gel electrophoresis, Michael O'Keefe and Ling Wan for technical support, and the University of Florida Interdisciplinary Center for Biotechnology Research (Gainesville) for the Desulfomicrobium apsheronum 16S rRNA sequence determination.

This research was supported in part by U.S. Environmental Protection Agency Cooperative Agreement CR 820062 with Mark E. Hines (University of New Hampshire).

\section{REFERENCES}

1. Amann, R. I., C. Lin, R. Key, L. Montgomery, and D. A. Stahl. 1992 Diversity among Fibrobacter isolates: towards a phylogenetic classification. Syst. Appl. Microbiol. 15:23-31.

2. Cheng, H. P., and T. G. Lessie. 1994. Multiple replicons constituting the genome of Pseudomonas cepacia 17616. J. Bacteriol. 176:4034-4042.

3. Chu, G. 1990 . Pulsed-field gel electrophoresis: theory and practice. Methods 1:129-142.

4. Devereux, R., S. H. He, C. L. Doyle, S. Orkland, D. A. Stahl, J. LeGall, and W. B. Whitman. 1990. Diversity and origin of Desulfovibrio species: phylogenetic definition of a family. J. Bacteriol. 172:3609-3619.

5. Fauque, G., J. LeGall, and L. L. Barton. 1991. Sulfate-reducing and sulfurreducing bacteria, p. 271-337. In J. M. Shively and L. L. Barton (ed.) Variations in autotrophic life. Academic Press, New York, N.Y.

6. Fox, G. E., J. D. Wisotzkey, and P. Jurtshuk, Jr. 1992. How close is close: 16S rRNA sequence identity may not be sufficient to guarantee species identity. Int. J. Syst. Bacteriol. 42:166-170.

7. Grothues, D., and B. Tummler. 1991. New approaches in genome analysis by pulsed-field gel electrophoresis: application to the analysis of Pseudomonas species. Mol. Microbiol. 5:2763-2776.

8. Johnson, J. L. 1991. DNA reassociation experiments, p. 21-44. In E. Stackebrandt and M. Goodfellow (ed.), Nucleic acid techniques in bacterial systematics. John Wiley and Sons, New York, N.Y.

9. Kawahara, F. K. 1971. Gas chromatographic analysis of mercaptans, phenols and organic acids in surface waters with use of pentafluorobenzyl derivatives. Environ. Sci. Technol. 5:235-239.

10. Kuo, C.-W., and B. R. Sharak Genthner. 1996. Effect of added heavy metal ions on biotransformation and biodegradation of 2-chlorophenol and 3-chlorobenzoate in anaerobic bacterial consortia. Appl. Environ. Microbiol. 62: 2317-2323.

11. Larsen, N., G. J. Olsen, B. L. Maidak, M. J. McCaughey, R. Overbeek, T. J. Macke, T. L. Marsh, and C. R. Woese. 1993. The Ribosomal RNA Database Project. Nucleic Acids Res. 21:3021-3023.

12. Lee, J. P., C. S. Yi, J. LeGall, and H. D. Peck. 1973. Isolation of a new pigment, desulforubidin, from Desulfovibrio desulfuricans (Norway strain) and its role in sulfite reduction. J. Bacteriol. 115:453-455.

13. Marmur, J., and P. Doty. 1962. Determination of the base composition of deoxyribonucleic acid from its thermal denaturation temperature. J. Mol. Biol. 5:109-118.

14. McClelland, M., R. Jones, Y. Patel, and M. Nelson. 1987. Restriction endonucleases for pulsed field mapping of bacterial genomes. Nucleic Acids Res. 15:5985-6005.

15. Miller, J. D. A., P. M. Neumann, L. Elford, and D. S. Wakerley. 1970. Malate dismutation by Desulfovibrio. Arch. Microbiol. 71:214-219.

16. Miller, J. D. A., and A. M. Saleh. 1964. A sulphate-reducing bacterium containing cytochrome $c_{3}$ but lacking desulfoviridin. J. Gen. Microbiol. 37: $419-423$. 
17. Miller, J. D. A., and D. S. Wakerley, 1966. Growth of sulphate-reducing bacteria by fumarate dismutation. J. Gen. Microbiol. 43:101-107.

18. Nazina, T. N., A. B. Poltaraus, and E. P. Rozanova. 1987. Estimation of genetic relationship of rod-shaped asporogenic sulfate-reducing bacteria. Microbiology (Engl. Transl. Mikrobiologiya) 56:669-672

19. Pfennig, N., F. Widdel, and H. G. Truper. 1981. The dissimilatory sulfatereducing bacteria, p. 926-940. In M. P. Starr, H. Stolp, H. G. Truper, A. Balows, and H. G. Schlegel (ed.), The prokaryotes. Springer-Verlag, Berlin, Germany.

20. Postgate, J. R. 1952. Growth of sulphate-reducing bacteria in sulphate-free media. Research (London) 5:189-190.

21. Postgate, J. R. 1959. A diagnostic reaction of Desulphovibrio desulphuricans. Nature (London) 183:481-482.

22. Postgate, J. R., and L. L. Campbell. 1966. Classification of Desulfovibrio species, the nonsporulating sulfate-reducing bacteria. Bacteriol. Rev. 30: $732-738$.

23. Raskin, L, W. C. Capman, M. D. Kane, B. R. Rittmann, and D. A. Stahl. 1996. Critical evaluation of membrane supports for use in quantitative hybridizations. Appl. Environ. Microbiol. 62:300-303.

24. Rozanova, E. P., and T. N. Nazina. 1976. A mesophilic, sulfate-reducing, rod-shaped, nonsporeforming bacterium. Microbiology (Engl. Transl. Mikrobiologiya) 45:711-716.

25. Rozanova, E. P., T. N. Nazina, and A. S. Galushko. 1988. Isolation of a new genus of sulfate-reducing bacteria and description of a new species of this genus, Desulfomicrobium apsheronum gen. nov., sp. nov. Microbiology
(Engl. Transl. Mikrobiologiya) 57:514-520.

26. Sharak Genthner, B. R., C. L. Davis, and M. P. Bryant. 1981. Features of rumen and sewage sludge strains of Eubacterium limosum, a methanol- and $\mathrm{H}_{2}-\mathrm{CO}_{2}$-utilizing species. Appl. Environ. Microbiol. 42:12-19.

27. Sharak Genthner, B. R., G. Mundfrom, and R. Devereux. 1994. Characterization of Desulfomicrobium escambium sp. nov. and proposal to assign Desulfovibrio desulfuricans strain Norway 4 to the genus Desulfomicrobium. Arch. Microbiol. 161:215-219.

28. Sharak Genthner, B. R., W. A. Price, and P. H. Pritchard. 1989. Anaerobic degradation of chloroaromatic compounds in aquatic sediments under a variety of enrichment conditions. Appl. Environ. Microbiol. 55:1466-1471.

29. Sharak Genthner, B. R., W. A. Price, and P. H. Pritchard. 1989. Characterization of anaerobic dechlorinating consortia derived from aquatic sediments. Appl. Environ. Microbiol. 55:1472-1476.

30. Thauer, R. K., K. Jungermann, and K. Decker. 1977. Energy conservation in chemoautotrophic anaerobic bacteria. Bacteriol. Rev. 41:100-180.

31. Wayne, L. G., D. J. Brenner, R. R. Colwell, P. A. D. Grimont, O. Kandler, M. I. Krichevsky, L. H. Moore, W. E. C. Moore, R. G. E. Murray, E. Stackebrandt, M. P. Starr, and H. G. Truper. 1987. Report of the Ad Hoc Committee on Reconciliation of Approaches to Bacterial Systematics. Int. J. Syst. Bacteriol. 37:463-464.

32. Weisburg, W. G., S. M. Barnes, D. A. Pelleteir, and D. J. Lane. 1991. 16S ribosomal DNA amplification for phylogenetic study. J. Bacteriol. 173:697703 